\title{
ECONOMY OF Biogas Plants
}

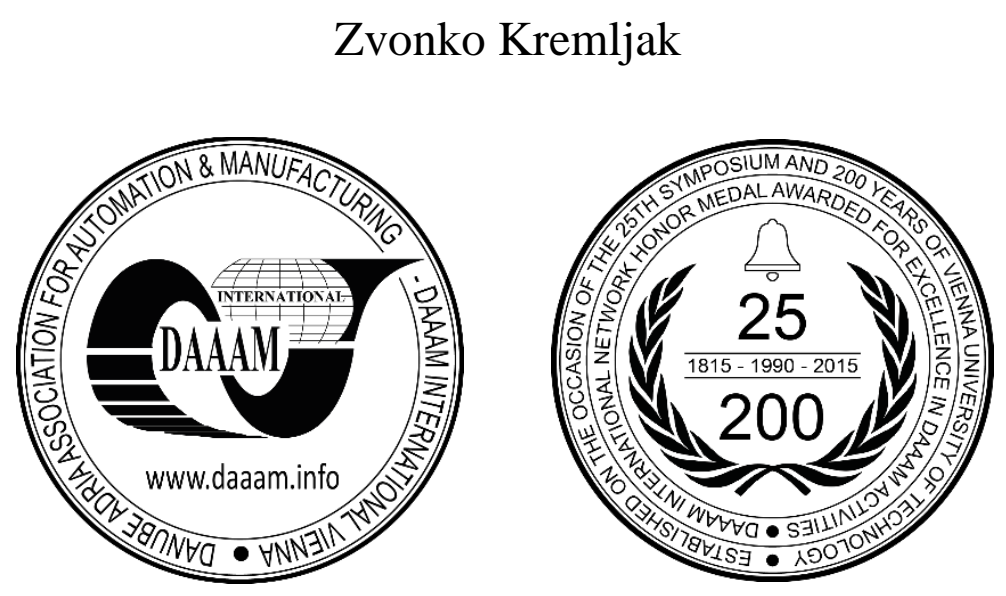

This Publication has to be referred as: Kremljak, Z[vonko] (2017). Economy of Biogas Plants, Proceedings of the 28th DAAAM International Symposium, pp.0136-0143, B. Katalinic (Ed.), Published by DAAAM International, ISBN 9783-902734-11-2, ISSN 1726-9679, Vienna, Austria DOI: $10.2507 / 28$ th.daaam.proceedings.018

\begin{abstract}
At a time when worldwide energy demand grows, the care for greener environment grows as well. Due to the extremely high energy potential, along the safety and cleanness of its operations, the biogas plant as an energy solution is deemed a great investment in the future. Frequently in that regard we face the question concerning the scope of the investment and the time needed for its return.

This paper gives an example of an investment in a biogas plant and the exploitation of renewable sources, which is simultaneously an example of circular economy. The biogas plant has a power of $1 \mathrm{MW}$, which along the existing concession prices and the resulting economy justifies the validity of the decision to invest while ensuring a cleaner environment. Invested funds shall be returned within a maximum of 6 years, reflecting the extremely dynamic business process.
\end{abstract}

Keywords: Biogas plant; Costs; Forecast; Profit; Electrical energy

\section{Introduction}

The current energy policy requires a constant technology development towards more sustainable energy transformation systems. Cogeneration and the use of renewables are two important solutions available to achieve this goal [1]. To analyse such systems from the point of view of resource efficiency, the pure energy analysis is not sufficient since the quality of particular energy carriers is not evaluated. Biogas projects demand high investments. Biogas plants are still experiencing harsh economic conditions [2]. Financing is therefore one of the key elements in order to ensure project viability. The financing scheme of a biogas plant project differs from country to country, but in general, low interest longterm loans are used. Ordinary mortgage loans are not frequently used. The index-regulated annuity loans are low-interest loans, which secure the investor against inflation through a re-evaluation of the unpaid debts according to the inflation rate. The pay-back period is more than 20 years. This type of loans proved to be the most suitable for financing the construction of biogas plants, meeting the demands for long maturity, low interest and low initial instalments. The disadvantages of such loans are that they are raised by ordinary sales of bonds at the stock exchange market price, implying a depreciation risk that may induce some uncertainty in the planning phase [3, 4]. In countries like Denmark, biogas projects are e.g. financed by means of index-regulated annuity loans, guaranteed by the municipalities. Most of the past biogas projects received also supplementary government subsidies, representing up to $30 \%$ of the investment costs of the project. 
A single farmer, a consortium of farmers or a municipality are usually the entrepreneurs likely to implement successful biogas projects. The success of the project depends on some factors that can be controlled and influenced by strategic decisions concerning investment and operational costs. Very few research studies exist on the positive effects of biogas production on the socio-economics of rural areas [5]. Considerable changes occur regarding the employment level. Additionally, in the majority of areas there is a significant potential for further development of biogas production, which would likewise be reflected in the effects of added value and employment opportunities. Farmers have heterogeneous investment thresholds. Their investment decisions are mainly driven by capital costs and the subjective perception of the risk resulting from the investment. Other decision parameters like sustainability and non-monetary objectives play only minor roles [6]. Choosing the best technology in respect of level of investment and operational costs is very difficult. If tendering a biogas plant, it is important receive offer on operational cost like:

- Operational cost of combined heat and power plant (CHP) incl. all services and spare parts (amount/kWh),

- Maintenance costs of biogas plant in total (\% of investment/year),

- Own electrical energy demand, including demand of CHP (kWh/year),

- Average working hours/day of staff (maintenance and feeding the system).

The success of the project is also influenced by some factors that cannot be controlled such as:

- Interest terms,

- Grid access and feed in tariffs,

- World market prices for feedstock (e.g. energy crops),

- Competition for feedstock from other sectors.

Industrial waste collectors face problems securing long term availability of the feedstock. This could be a problem because the waste recycling market is highly competitive and contracts with waste producers are rarely for periods longer than five years.

Quite often, before a bank offers to finance the biogas plant project, the economical long term success of the project must be proven by a study/ calculation of profitability [7]. The calculation is normally done within the preliminary planning by an experienced planning/consulting company, but in many cases, especially in the case of single based biogas projects, this work can be done by the project developer, with two consequently advantages: the project developers/partners are forced to have a very close view to the different aspects of the project and, in case of cancelling the project, no external costs have occurred.

\section{Economic forecast of a biogas plant project}

In a case of a biogas plant treating municipal waste, it is recommended to mandate an experienced consulting company. Waste treatment plants are much more complex regarding handling of feedstock, biological stability of the system and the whole plant design, compared to a farm based plant (Fig. 1).

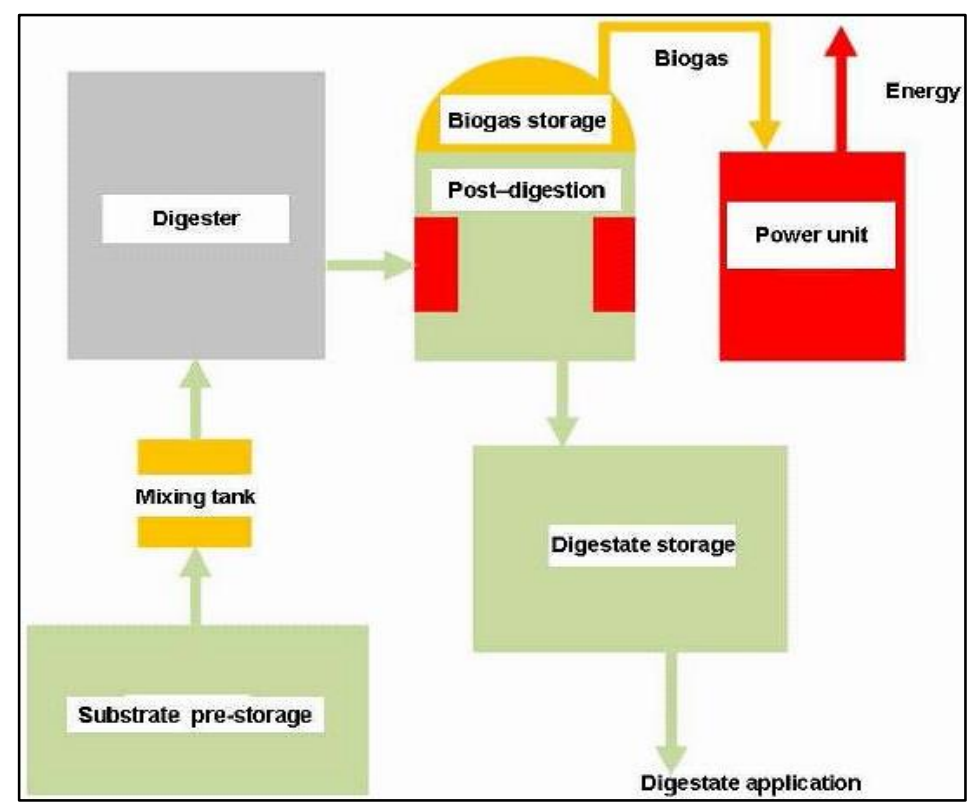

Fig. 1. Main components and general process flow of biogas production 
For case specific calculation of the economic forecast, a calculation model was elaborated, allowing the preliminary estimation of costs, plant size, dimensioning, technical outline etc. finding an independent and reliable planning partner is mandatory. The framework conditions of organic biogas generation and its monetary implications on production economics must be carefully analysed [8] and [9], with risks evaluation [10]. Renewable energy production is not economically viable by its own, without considering the wastewater treatment function and the associated incomes [11].

\section{Project case}

For the purpose of construction of the biogas plant, land in area of 1.4 ha is being purchased. The Ministry of economy has issued a preliminary electricity permission needed in order to construct the plant with bio power of $1 \mathrm{MWh}$ based on prior economic and technological analyses.

Collection of waste from farms represents an ecological problem because raw manure cannot be immediately (due to its high concentration and / or vegetation period) used on arable land as fertilizer. The waste is therefore collected or deposited along the fields in inadequate (usually permeable) reservoirs / disposal sites / lagoons from where they penetrate into the surface and ground waters, polluting them. Stench and even more important pollution from glass gases $\left(\mathrm{NH}_{3}\right.$, $\left.\mathrm{CO}_{2}, \mathrm{CH}_{4}, \mathrm{H}_{2} \mathrm{~S}\right)$, that destroy the ozone layer, are expanding.

\subsection{Project goals}

Three main goals need to be achieved:

- Tackling environmental problems and at the same time exploiting "waste" traits as a renewable source of energy,

- Exploitation of processed and fermented residue as a high caloric organic fertilizer,

- Development of energy crops (silages) with the aim of improving the energy efficiency with partial exploitation of fertilizer produced on site.

The raw material for the biogas plant will be purchased in the environmental field on approximately 10,000 hectares of arable land, which provides a minimum of 10,000 tons of biomass with the price of $17 € /$ tonne. The production itself is agreed for a reason that it should not endanger food production and should take the arable land. Deficiencies of the contracts for inbounds are identified as price hikes of the raw materials required for the upcoming biogas plant and the price hikes of the agricultural products, corn in particular. In absence of price hikes regarding the biogas production, longterm contracts for period of 10-12 years are suggested to be signed. In terms of the biomass price the following formula is applied:

$$
C_{\text {Goie }}=C_{\text {Goie-1 }} \times I C M_{\text {Goie-1 }}
$$

- $C_{\text {Goie }}$ is the purchase price for the current year,

- $C_{\text {Goie-1 }}$ is the purchase price for the previous year,

- $I C M_{\text {Goie-1 }}$ is an annual index of growth of the retail prices in terms of the previous year,

- Goie is an annual index, the minimum value in the year.

Plants connected to the distribution network with installed electrical power up to $1 \mathrm{MW}$, which use renewable sources of energy for its production, sell such energy under the price of $0,174 € / \mathrm{kWh}$, with no value added tax (VAT) calculated.

The raw material is delivered to the cleaver and the blender by pressure pipeline and/or tanks, where it is mixed with silage, other biodegradable substrates (waste material) and hot water (heated with the surplus of the heat already generated), after what it is dosed in an equalization pool, mixed with a submerging device. The liquid is being pumped from the pool into a hydrolyser, where for 2-3 days a hydrolysis is commencing on temperature of approx. $55^{\circ} \mathrm{C}$. The heating is carried out by heat exchanger of the water heated with the surplus of the produced heat (hot water). The hydrolysate is pumped onwards into a digester - 1, where for 15-20 days a thermophilic conversion of hydrolysed organic substances into biogas is commencing on temperature of approx. $55^{\circ} \mathrm{C}$ [12]. The heating is carried out by heat exchanger of the water heated with the surplus of the produced heat (hot water). Ferment thickens by passing through the separator and thus condensed, pumps through the reservoir, where the conversion into biogas continues, accumulating in the gas tank / in the dome above the reservoir. In that gas tank, the biogas is dosed from the dome of the digester - 1 . Reservoir - ferment will be soon built for the phase II as well, thus the initial period of retention of the ferment shall take approx. 30 days, whilst in the second phase it shall decrease [13].

The obtained biogas is purified by aerobic biological conversion of sulphide into elementary sulphur at the top of the dome and by removing the moisture by passing through the capacitors and the filters. Later on the obtained biogas is used for drive of CHP units which are used in the production of electrical and thermal energy. 
Processed and fully stabilized fermenter (without odour) is transported through the same reservoirs, which are used for delivery of the substrate to the smaller reservoirs (container, metal or terrestrial), mounted on arable areas as high calorific organic fertilizer with corresponding tractor hitch. Optionally it can be one of the larger reservoirs (which holds fermenter for approx. 90 days, during the vegetation period), from which the fertilizer can be deprived if necessary.

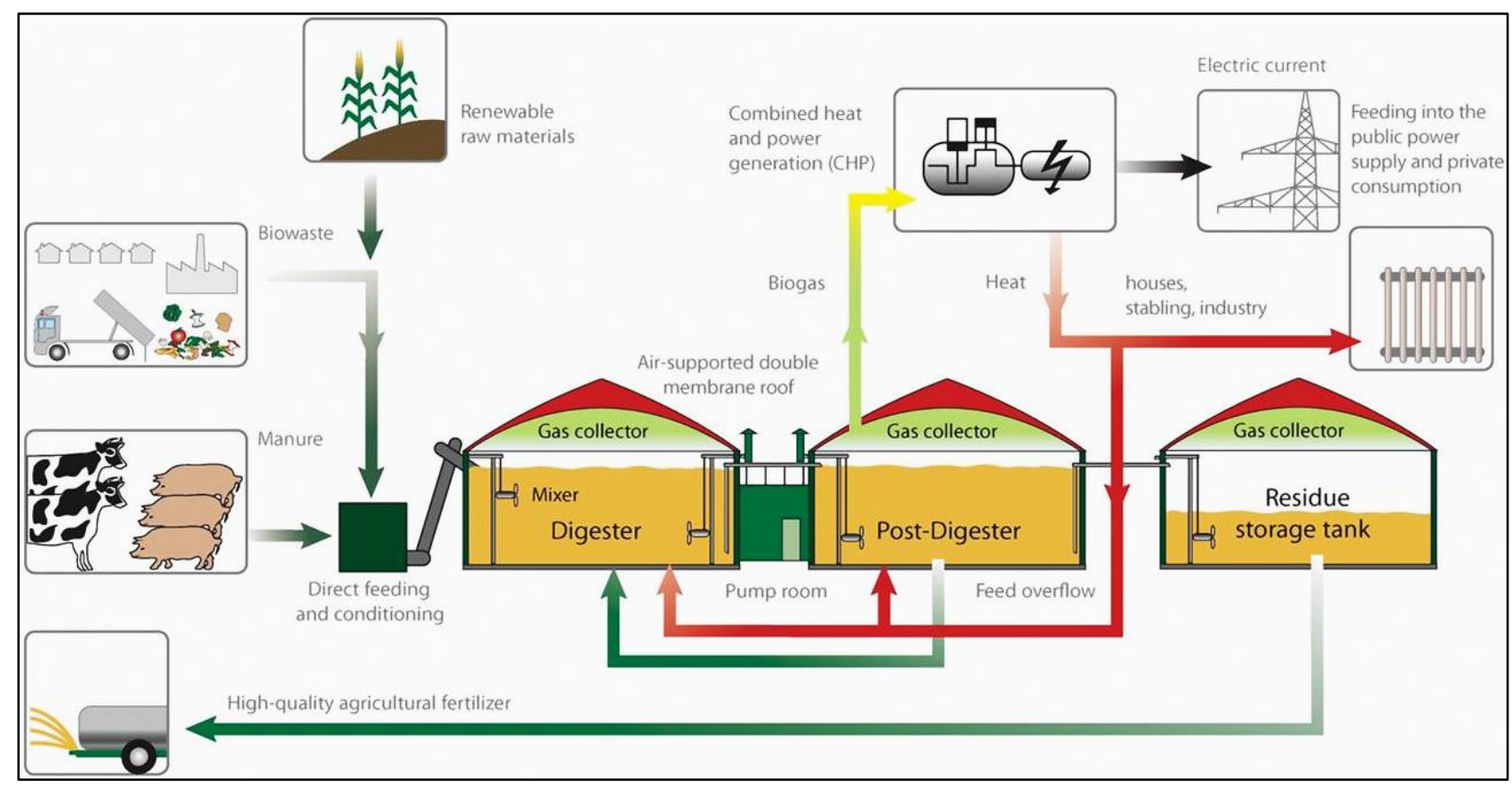

Fig. 2. Technological process of the biogas plant

The biogas plant will be installed at a location with good infrastructure in terms of logistical point of view. At $500 \mathrm{~m}$ distance from the bioplant there is a transformer-station with an option to connect to the network.

Possible impacts of the construction of biogas plant on the surrounding area can affect the soil, underground and groundwater, the air and the "production" waste. Negative impact can occur on soil and subsoil in case of outlet of the liquid manure. In that case the liquid manure will penetrate into the underground, in particular into the underground water or it will reach the recipient on the surface, where it can destroy the living world due to lack of oxygen. In order to prevent such negative impact, the manure is deposited into closed reservoirs.

The impact on air is unfavourable odour-stench from the biogas plant because of the silage, the livestock faeces, aggregate pits for wastewater from the silages and the reservoirs for the fermented manure. It is considered that the stench reaches an area of $500 \mathrm{~m}$, whilst in terms of unfavourable weather conditions it can reach an area of up to $1 \mathrm{~km}$. Closest living areas are $1 \mathrm{~km}$ away, which means that it shall not affect the area of residential neighbourhoods.

In order to monitor the state of the environment, regular controls and analyses on the underground water shall be performed, whilst once in two years' time analyses on the soil, which are fertilized by the fermented liquid manure from the plant shall be commenced as well. The construction of the biogas plant creates jobs, new values and raises the awareness of the usage of renewable sources.

\section{Economic and financial analysis}

The input data and the results of the analysis for the observed 10 years are summarised in tables 1 to 8 . We have developed the cost model considering all fixed values of parameters (some of them are fixed by the government regulation or market situation) and some cost components giving us some optimisation possibilities.

\begin{tabular}{|l|c|c|c|}
\hline \multicolumn{1}{|c|}{ Description } & Equipment value & Amortization period & Annual depreciation \\
\hline Construction works & $707.616 €$ & 20 & $35.381 €$ \\
\hline Equipment & $2.153 .164 €$ & 10 & $215.316 €$ \\
\hline Cogeneration unit & $739.220 €$ & 7 & $105.603 €$ \\
\hline Total & $\mathbf{3 . 6 0 0 . 0 0 0} €$ & & $356.300 €$ \\
\hline
\end{tabular}

Table 1. Total investment costs 


\begin{tabular}{|l|r|}
\hline \multicolumn{1}{|c|}{ Description } & Price (€) \\
\hline Construction works & 707.616 \\
\hline Electro-mechanical equipment and works & 2.672 .384 \\
\hline Engineering & 220.000 \\
\hline Silage purchase in first year of business & 220.000 \\
\hline Total & $\mathbf{3 . 8 2 0 . 0 0 0}$ \\
\hline
\end{tabular}

Table 2. Total infrastructure costs

\begin{tabular}{|c|l|c|c|}
\hline No. & \multicolumn{1}{|c|}{ Service / Equipment } & Capacity & Value \\
\hline 1. & Design / Construction & & $135.000 €$ \\
\hline 2. & Commissioning (Momentum) & & $65.000 €$ \\
\hline 3. & Design of plans for location permit & & $20.000 €$ \\
\hline 4. & Static budget & & V \\
\hline 5. & Apparatus for receiving solids & & $149.838 €$ \\
\hline 6. & Reception reservoir of liquid manure & & $16.977 €$ \\
\hline 7. & Digester charging room & & $105.596 €$ \\
\hline 8. & Digester 1 & $3.115 \mathrm{~m}^{3}$ & $406.403 €$ \\
\hline 9. & Digester 2 & $3.115 \mathrm{~m}^{3}$ & $406.403 €$ \\
\hline 10. & Post reservoir with associated gas-tank & & $230.792 €$ \\
\hline 11. & CHP & Approx. $999 \mathrm{~kW}_{\mathrm{el}}$ & $739.220 €$ \\
\hline 12. & Safety torch & & \\
\hline 13. & Desulfurization of biogas & & \\
\hline 14. & Scale (quantity: 1 ) & $30 \mathrm{t}$ & \\
\hline 15. & Measuring, monitoring and control equipment & & $284.625 €$ \\
\hline 16. & Dehydration of sludge & & $53.590 €$ \\
\hline 17. & Laguna for post-fermented mass & & \\
\hline 18. & Condensing pool & & $100.000 €$ \\
\hline 19. & Design of pipelines & & $61.640 €$ \\
\hline 20. & Insurance, transport & & $\mathbf{2 . 8 9 2 . 3 8 4} €$ \\
\hline & Plant expenses & & $\mathbf{7 0 7 . 6 1 6} €$ \\
\hline & Infrastructure expenses & & $274.700 €$ \\
\hline 1. & Silage silo & & $80.000 €$ \\
\hline 2. & Earthworks and asphalt bases (quantity: 2000$)$ & & $54.000 €$ \\
\hline 3. & Other earthworks & & $138.966 €$ \\
\hline 4. & Foundations & & $125.000 €$ \\
\hline 5. & Substation & & $34.950 €$ \\
\hline 6. & Starting cost & & \\
\hline & Total investment & & \\
\hline & & & \\
\hline
\end{tabular}

Table 3. Detailed specification of equipment, material and labour

\begin{tabular}{|c|c|c|c|c|c|c|c|c|c|c|}
\hline Structure IYear & 1 & 2 & 3 & 4 & 5 & 6 & 7 & 8 & 9 & 10 \\
\hline \multicolumn{11}{|l|}{ Revenue } \\
\hline Thermal energy & 0 & 31.906 & 32.864 & 33.850 & 34.865 & 35.911 & 36.988 & 38.098 & 39.241 & 40.418 \\
\hline Electricity & 730.037 & 1.417 .548 & 1.460 .074 & 1.502 .601 & 1.545 .127 & 1.587 .654 & 1.630 .180 & 1.672 .707 & 1.715 .233 & 1.757 .760 \\
\hline \multicolumn{11}{|l|}{$\begin{array}{l}\text { Value of the } \\
\text { organic } \\
\text { fertilizers }\end{array}$} \\
\hline Total revenue & 730.037 & 1.449 .455 & 1.492 .938 & 1.536 .450 & 1.579 .992 & 1.623 .565 & 1.667 .169 & 1.710 .805 & 1.754 .474 & 1.798 .178 \\
\hline \multicolumn{11}{|l|}{ Costs } \\
\hline \multicolumn{11}{|l|}{ Loan repayment } \\
\hline \multicolumn{11}{|l|}{ Interest } \\
\hline Depreciation & 178.150 & 356.300 & 356.300 & 356.300 & 356.300 & 356.300 & 356.300 & 356.300 & 356.300 & 356.300 \\
\hline $\begin{array}{l}\text { Maintenance } \\
\text { of the plant }\end{array}$ & & 16.802 & 16.802 & 33.605 & 33.605 & 33.605 & 33.605 & 33.605 & 50.407 & 50.407 \\
\hline $\begin{array}{l}\text { Maintenance } \\
\text { of the CHP }\end{array}$ & 47.875 & 119.689 & 123.280 & 126.870 & 130.461 & 134.052 & 137.642 & 141.233 & 144.824 & 148.414 \\
\hline Insurance & 10.000 & 10.000 & 10.300 & 10.609 & 10.927 & 11.255 & 11.593 & 11.941 & 12.299 & 12.668 \\
\hline Fuel & 5.833 & 10.000 & 10.300 & 10.609 & 10.927 & 11.255 & 11.593 & 11.941 & 12.299 & 12.668 \\
\hline
\end{tabular}




\begin{tabular}{|l|c|c|c|c|c|c|c|c|c|c|}
\hline $\begin{array}{l}\text { Fermented mass } \\
\text { supply costs }\end{array}$ & & 38.245 & 39.010 & 39.790 & 40.586 & 41.398 & 42.226 & 43.070 & 43.932 & 44.810 \\
\hline $\begin{array}{l}\text { Raw materials } \\
\text { costs (Silage) }\end{array}$ & 110.000 & 220.000 & 226.600 & 233.398 & 240.400 & 247.612 & 255.040 & 262.692 & 270.572 & 278.689 \\
\hline $\begin{array}{l}\text { Monitoring of } \\
\text { the biological } \\
\text { process }\end{array}$ & & 2.340 & 2.410 & 2.483 & 2.557 & 2.634 & 2.713 & 2.794 & 2.878 & 2.964 \\
\hline Workforce & 12.775 & 21.900 & 22.557 & 23.234 & 23.931 & 24.649 & 25.388 & 26.150 & 26.934 & 27.742 \\
\hline Spare parts & 9.946 & 19.893 & 20.091 & 20.292 & 20.495 & 20.700 & 20.907 & 21.116 & 21.327 & 21.541 \\
\hline Total costs & 374.579 & 815.169 & 827.650 & 857.190 & 870.190 & 883.460 & 897.007 & 910.841 & 941.771 & 956.203 \\
\hline EBITDA & 355.458 & 634.285 & 665.288 & 679.261 & 709.803 & 740.105 & 770.162 & 799.964 & 812.703 & 841.974 \\
\hline
\end{tabular}

Table 4. Profit and loss statement (part 1)

\begin{tabular}{|l|c|c|c|c|c|c|c|c|c|c|}
\hline Structure \Year & $\mathbf{1}$ & $\mathbf{2}$ & $\mathbf{3}$ & $\mathbf{4}$ & $\mathbf{5}$ & $\mathbf{6}$ & $\mathbf{7}$ & $\mathbf{8}$ & $\mathbf{9}$ & $\mathbf{1 0}$ \\
\hline I. Revenue & 730.037 & 1.449 .455 & 1.492 .938 & 1.536 .450 & 1.579 .992 & 1.623 .565 & 1.667 .169 & 1.710 .805 & 1.754 .474 & 1.798 .178 \\
\hline 1. Total revenue & 730.037 & 1.449 .455 & 1.492 .938 & 1.536 .450 & 1.579 .992 & 1.623 .565 & 1.667 .169 & 1.710 .805 & 1.754 .474 & 1.798 .178 \\
\hline 2. Rest of project & 0 & 0 & 0 & 0 & 0 & 0 & 0 & 0 & 0 & 0 \\
\hline 2.1. Fixed assets & & & & & & & & & & \\
\hline II. Expenditures & 319.979 & 787.306 & 798.688 & 822.059 & 833.899 & 845.909 & 858.234 & 870.813 & 895.414 & 908.522 \\
\hline $\begin{array}{l}\text { 3. Fixed assets } \\
\text { investments }\end{array}$ & & & & & & & & & & \\
\hline 4. Operating costs & 200.596 & 458.869 & 471.350 & 500.890 & 513.889 & 527.159 & 540.707 & 554.541 & 585.471 & 599.903 \\
\hline 4.1.Tangible costs & 177.821 & 426.969 & 438.493 & 467.047 & 479.031 & 491.255 & 503.726 & 516.450 & 546.239 & 559.494 \\
\hline 4.2. Service costs & 10.000 & 10.000 & 10.300 & 10.609 & 10.927 & 11.255 & 11.593 & 11.941 & 12.299 & 12.668 \\
\hline $\begin{array}{l}\text { 4.3. Intangible } \\
\text { costs }\end{array}$ & & & & & & & & & & \\
\hline 4.4. Gross salaries & 12.775 & 21.900 & 22.557 & 23.234 & 23.931 & 24.649 & 25.388 & 26.150 & 26.934 & 27.742 \\
\hline 5. Profit tax & 79.589 & 218.958 & 218.225 & 214.112 & 213.340 & 212.499 & 211.685 & 210.848 & 206.628 & 205.746 \\
\hline 6. Reserves & 39.794 & 109.479 & 109.113 & 107.056 & 106.670 & 106.250 & 105.842 & 105.424 & 103.314 & 102.873 \\
\hline III. Net revenue & 410.058 & 662.148 & 694.250 & 714.392 & 746.093 & 777.656 & 808.935 & 839.992 & 859.060 & 889.656 \\
\hline
\end{tabular}

Table 5. Profit and loss statement (part 2)

\begin{tabular}{|c|c|c|c|c|c|c|c|c|c|c|}
\hline Structure \ Year & 1 & 2 & \begin{tabular}{|l|}
3 \\
\end{tabular} & 4 & 5 & \begin{tabular}{|l|}
6 \\
\end{tabular} & \begin{tabular}{|l|}
7 \\
\end{tabular} & 8 & 9 & 10 \\
\hline I. Revenue & 4.330 .037 & 1.449 .455 & \begin{tabular}{|l|}
1.492 .938 \\
\end{tabular} & 1.536 .450 & \begin{tabular}{|l|}
1.579 .992 \\
\end{tabular} & 1.623 .565 & \begin{tabular}{|l|}
1.667 .169 \\
\end{tabular} & 1.710 .805 & \begin{tabular}{|l|}
1.754 .474 \\
\end{tabular} & 1.798 .178 \\
\hline 1. Total revenue & 730.037 & 1.449 .455 & 1.492 .938 & 1.536 .450 & \begin{tabular}{|l|}
1.579 .992 \\
\end{tabular} & 1.623 .565 & \begin{tabular}{|l|}
1.667 .169 \\
\end{tabular} & 1.710 .805 & \begin{tabular}{|l|}
1.754 .474 \\
\end{tabular} & 1.798 .178 \\
\hline $\begin{array}{l}2 \text {. Funding } \\
\text { sources }\end{array}$ & 3.600 .000 & 0 & 0 & 0 & 0 & 0 & 0 & 0 & 0 & 0 \\
\hline \begin{tabular}{|l|}
2.1. Own \\
resources
\end{tabular} & 720.000 & & & & & & & & & \\
\hline 2.1. Loans & 2.880 .000 & & & & & & & & & \\
\hline 3. Rest of project & \begin{tabular}{|l|}
0 \\
\end{tabular} & 0 & 0 & 0 & 0 & 0 & 0 & 0 & 0 & 0 \\
\hline 3.1. Fixed assets & & & & & & & & & & \\
\hline II. Expenditures & 200.596 & 883.634 & 896.115 & 925.655 & 938.655 & 951.925 & 965.472 & 979.306 & 1.010 .237 & 1.024 .669 \\
\hline \multicolumn{11}{|l|}{$\begin{array}{l}\text { 4. Investments in } \\
\text { fixed assets }\end{array}$} \\
\hline $\begin{array}{l}\text { 5. Operational } \\
\text { costs }\end{array}$ & 200.596 & 458.869 & 471.350 & 500.890 & 513.889 & 527.159 & 540.707 & 554.541 & 585.471 & 599.903 \\
\hline $\begin{array}{l}\text { 5.1. Tangible } \\
\text { costs }\end{array}$ & 177.821 & 426.969 & 438.493 & 467.047 & 479.031 & 491.255 & 503.726 & 516.450 & 546.239 & 559.494 \\
\hline $\begin{array}{l}\text { 5.2. Services } \\
\text { costs }\end{array}$ & 10.000 & 10.000 & 10.300 & 10.609 & 10.927 & 11.255 & 11.593 & 11.941 & 12.299 & 12.668 \\
\hline $\begin{array}{l}\text { 5.3. Intangible } \\
\text { costs }\end{array}$ & 0 & 0 & 0 & 0 & 0 & 0 & 0 & 0 & 0 & 0 \\
\hline 5.4. Gross salaries & 12.775 & 21.900 & 22.557 & 23.234 & 23.931 & 24.649 & 25.388 & 26.150 & 26.934 & 27.742 \\
\hline 6. Profit tax $20 \%$ & 0 & 0 & 0 & 0 & 0 & 0 & 0 & 0 & 0 & 0 \\
\hline 7. Reserves & 0 & 0 & 0 & 0 & 0 & 0 & 0 & 0 & 0 & 0 \\
\hline 8. Annuities & 0 & 424.765 & 424.765 & 424.765 & 424.765 & 424.765 & 424.765 & 424.765 & 424.765 & 424.765 \\
\hline III. Net revenue & 4.129 .441 & 565.820 & 596.823 & 610.795 & 641.338 & 671.640 & 701.696 & 731.499 & 744.237 & 773.509 \\
\hline $\begin{array}{l}\text { IV. Cumulative } \\
\text { net revenue }\end{array}$ & 4.129.441 & 4.695 .261 & 5.292 .084 & 5.902 .880 & 6.544 .217 & 7.215 .858 & 7.917.554 & 8.649 .053 & 9.393 .290 & 10.166 .799 \\
\hline
\end{tabular}

Table 6. Economic flow of project 


\begin{tabular}{|l|c|c|c|c|}
\hline \multicolumn{1}{|c|}{ Month } & Monthly production & Own consumption & Energy for sale & Rest \\
\hline January & 662.400 & 198.720 & 463.680 & 0 \\
\hline February & 662.400 & 198.720 & 463.680 & 0 \\
\hline March & 662.400 & 198.720 & 463.680 & 0 \\
\hline April & 662.400 & 158.976 & 302.054 & 201.370 \\
\hline May & 662.400 & 0 & 264.960 & 397.440 \\
\hline June & 662.400 & 0 & 0 & 662.400 \\
\hline July & 662.400 & 0 & 0 & 662.400 \\
\hline August & 662.400 & 0 & 0 & 662.400 \\
\hline September & 662.400 & 0 & 198.720 & 463.680 \\
\hline October & 662.400 & 59.616 & 361.670 & 241.114 \\
\hline November & 662.400 & 99.360 & 563.040 & 0 \\
\hline December & 662.400 & 198.720 & 463.680 & 0 \\
\hline Total per annum & 7.948 .800 & 1.112 .832 & 3.545 .164 & 3.290 .804 \\
\hline
\end{tabular}

Table 7. Production balance of thermal energy (in KWh)

Consumption of thermal energy for own needs is $55 \%$.

\begin{tabular}{|l|c|c|c|}
\hline \multicolumn{1}{|c|}{ Month } & Monthly production & Capacity $(\mathrm{kW})$ & Daily production $(\mathrm{h})$ \\
\hline January & 674.505 & 999 & 21,78 \\
\hline February & 609.230 & 999 & 21,78 \\
\hline March & 674.505 & 999 & 21,78 \\
\hline April & 652.747 & 999 & 21,78 \\
\hline May & 674.505 & 999 & 21,78 \\
\hline June & 652.747 & 999 & 21,78 \\
\hline July & 674.505 & 999 & 21,78 \\
\hline August & 674.505 & 999 & 21,78 \\
\hline September & 652.747 & 999 & 21,78 \\
\hline October & 674.505 & 999 & 21,78 \\
\hline November & 652.747 & 999 & 21,78 \\
\hline December & 674.505 & 999 & 21,78 \\
\hline Average & 661.813 & 999 & 21,78 \\
\hline Total per annum & 7.941 .750 & - & 7949,7 \\
\hline
\end{tabular}

Table 8. Production of electricity (in KWh)

Consumption of electricity for own needs of the biogas plant is $6 \%$ or $476.505 \mathrm{kWh}$. During operation, we have a computer control loop, which indicates that we are running within planned costs, within the achievement of the planned objectives and within other technical parameters. All technical parameters and costs, eventual failures are controlled by dedicated software. Any deviations are displayed using visual warning signal, overall control can also be remotely controlled and synchronized with the network. This ensures a stable economic operation of the plant.

\section{Conclusion}

Production and consequently sales of energy derived from biogas production devices offers economic opportunity for treatment and recycling of many agricultural residues and by-products, a variety of bio-waste, organic waste water from industry and sewage in a sustainable and environmentally friendly manner.

Having done the pre-calculations using the calculation tool as recommended in the result is a model of the economy of the project. As stated before, the operational costs and the investment costs can be influenced by strategic decisions. For example by choosing the best adapted technology. So, if labour is cheap in your country, than it might be cheaper engaging more people than spending money for automation of a plant.

The revenue side of a project is difficult to influence. The feed in tariffs are set by the government. In case of waste treatment plants, the tipping fees are market prices. There are other possibilities of improve the revenue side:

- Using/selling the produced heat,

- Selling digestant as a fertilizer. 
If the project obtains an internal rate of return (IRR) lower than $9 \%$, you should reconsider all the project premises, and improve some of them. If the IRR rate is higher than $9 \%$, the premises are good and it is worth continuing the project and moving to the next planning phase. It is important to compare the assumptions with the material reality. This helps to get a realistic idea of the biogas plant itself, the needed space, the true mass current and the real building costs. The calculation model is useful for providing the rough information which is necessary to kick start the actual planning phase. Also the earnings before interest, taxes, depreciation and amortization (EBITDA) are very prosperous. For the next steps of project, finding an independent and reliable planning partner is mandatory.

According to the economic indicators, return on the whole investment is anticipated in 5-6 years. The lifetime of the biogas plant is 20 years. The plant itself delivers 5 jobs, whilst it indirectly ensures 20 jobs including production of biomass on the fields. The utilization of the fermented mass as organic fertilizer improves crops contribution for $15-25 \%$ and reduces the application of artificial fertilizers, which as a result improves the total quality of the agricultural production and decreases the artificial fertilizers expenses. In the biogas plant, the waste is used as bio-renewable source of energy.

The main paper contribution is the development of new structure of cost calculation applying a wide list of influencing parameters which consider the actual state and conditions. Another achievement is the modified system of evaluation of the eligibility of investment. In future research some model expansions are planned, including the generalization of implemented (combined) energy sources.

\section{References}

[1] Stanek, W.; Gazda, W. \& Kostowski, W. (2015). Thermo-ecological assessment of CCHP (combined cold-heatand-power) plant supported with renewable energy. Energy, Vol. 92, Special issue - Part 3, 279-289, ISSN 03605442

[2] Ahlberg-Eliasson, K.; Nadeau, E.; Leven, L. \& Schnurer, A. (2017). Production efficiency of Swedish farm-scale biogas plants. Biomass \& Bioenergy, Vol. 97, 27-37, ISSN 0961-9534

[3] Glavan, I.; Prelec, Z. \& Pavkovic, B. (2015). Modelling, simulation and optimization of small-scale CCHP energy systems. International Journal of Simulation Modelling, Vol. 14, No. 4, 683- 696, ISSN 1726-4529

[4] Kang, J. Y.; Kang, D. W.; Kim, T. S. \& Hur, K. B. (2014). Comparative economic analysis of gas turbine-based power generation and combined heat and power systems using biogas fuel. Energy, Vol. 67, 309-318, ISSN 03605442

[5] Guenther-Luebbers, W.; Bergmann, H. \& Theuvsen, L. (2016). Potential analysis of the biogas production - as measured by effects of added value and employment. Journal of Cleaner Production, Vol. 129, 556-564, ISSN 09596526

[6] Reise, C.; Musshoff, O.; Granoszewski, K. \& Spiller, A. (2012). Which factors influence the expansion of bioenergy? An empirical study of the investment behaviours of German farmers. Ecological Economics, Vol. 73, 133-141, ISSN 0921-8009

[7] Lai, X. D.; Wu, G.-D.; Shi, J. G.; Wang, H. M. \& Kong, Q. S. (2015). Project value-adding optimization of projectbased supply chain under dynamic reputation incentives. International Journal of Simulation Modelling, Vol. 14, No. 1, 121-133, ISSN 1726-4529

[8] Blumenstein, B.; Siegmeier, T. \& Moeller, D. (2016). Economics of anaerobic digestion in organic agriculture: Between system constraints and policy regulations. Biomass \& Bioenergy, Vol. 86, 105-119, ISSN 0961-9534

[9] Krajnc, M.; Dolsak, B. (2013). Computer and experimental simulation of biomass production using drum chipper. International Journal of Simulation Modelling, Vol. 12, No. 1, 39-49, ISSN 1726-4529

[10] Kremljak, Z. (2016). Risk analysis of specific project problems. Proceedings of the $27^{\text {th }}$ International DAAAM Symposium "Intelligent Manufacturing \& Automation", October 2016, Mostar, Bosnia \& Herzegovina, ISSN 23041382, ISBN 978-3-902734-3-6, Katalinic, B. (Ed.), 8 pages, DAAAM International Vienna

[11] Fersi, S.; Chtourou, N.; Jury, C. \& Poncelet, F. (2015). Economic analysis of renewable heat and electricity production by sewage sludge digestion - a case study. International Journal of Energy Research, Vol. 39, No. 2, 234-243, ISSN 1099-114X

[12] Voegel, V.; Bertron, A. \& Erable, B. (2016). Mechanisms of cementitious material deterioration in biogas digester. Science of The Total Environment, Vol. 571, 892-901, ISSN 0048-9697

[13] Siswantara, A. I.; Daryus, A.; Darmawan, S.; Gunadi, G. G. \& Camalia, R. (2016). CFD analysis of slurry flow in an anaerobic digester. International Journal of Technology, Vol. 7, No. 2, 197-203, ISSN 2086-9614 